\title{
New data on Late Turonian crinoids from the Bohemian Cretaceous Basin, Czech Republic
}

\author{
JIŘí ŽÍTT \& RADEK VODRÁŽKA
}

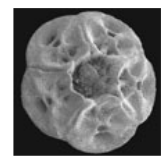

\begin{abstract}
Crinoid faunas from scour and burrow fills in the basal portions of the Upper Turonian Teplice Formation at the locality Úpohlavy, Bohemian Cretaceous Basin (BCB) comprise the bourgueticrinid Bourgueticrinus ex gr. fischeri (Geinitz, 1872) represented by cups, proximalia and columnals and, in contrast, the comatulid Placometra ex gr. laticirra (Carpenter, 1880), new to the BCB, preserved as complete cups. Analysis of articulated portions of arms and dissociated brachials in the assemblages allows specimens to be identified and assigned to Bourgueticrinus ex gr. fischeri?, Placometra ex gr. laticirra?, Placometra? sp. and "Isocrinus" sp. The original echinoderm community also included an indeterminate bourgueticrinid with "rhizocrinid" columnals. Life habits and taphonomy of these crinoids are discussed. The type specimen of Bourgueticrinus fischeri from similar crinoid associations in Saxony is in need of revision. Key words: Echinodermata, Crinoidea, taxonomy, taphonomy, Late Turonian, Bohemian Cretaceous Basin.
\end{abstract}

ŽíTT, J. \& VODRÁŽKA, R. 2008. New data on Late Turonian crinoids from the Bohemian Cretaceous Basin, Czech Republic. Bulletin of Geosciences 83(3), 311-326 (8 figures, 2 tables). Czech Geological Survey, Prague. ISSN 1214-1119. Manuscript received July 31, 2008; accepted in revised form September 1, 2008, issued September 30, 2008.

Jiří Žitt, Academy of Sciences of the Czech Republic, Institute of Geology, Rozvojová 269, 16502 Praha 6, Czech Republic; zitt@gli.cas.cz・Radek Vodrážka, Czech Geological Survey, Klárov 3/131, 11821 Praha 1, Czech Republic; radek.vodrazka@geology.cz.

Most of the crinoid taxa known to date from the Bohemian Cretaceous Basin (BCB) occur in Lower Turonian strata of central Bohemia (e.g., Frič 1911; Rasmussen 1961; Žítt 1993, 1996; Žítt et al. 2006). Among these, only some earlier references to the presence of Bourgueticrinus (see below synonymy of $B$. ex gr. fischeri) from northwestern Bohemia are known, for instance those from Lužice (Luschitz), Kyselka (Sauerbrunnberg), Křtěnov (Kröndorf), Želenice (Schillinge), Kučlín (Kutschlin) (all of these localities are close to Bílina), Březno (Priesen), Koštice (Kosstitz) (both near Louny), Novosedlice (Weisskirchlitz) near Teplice, Třebívlice (Trziblitz, "Pyropensand Böhmen") (NNE of Louny) (see Reuss 1844, 1845-1846; Geinitz 1849-1850), Chvojenec near Děčín (see Jahn 1895) and Doubek near Oparno (see Zahálka 1914). Zahálka (1914) referred these localities to the uppermost portion of his informal unit IX as well as to unit X (not verified, but probably Upper Turonian for the most part). Of interest are crinoid remains from the Březno Formation (dated as Coniacian by Čech et al. 1996), as collected by Frič (1895), who noted columnals and brachials (assigned to Antedon fischeri) at Lužice near Bílina and at Březno near Louny. One columnal and a single distal stem part with radicular cirri, collected at Březno, were illustrated by him (Frič 1895, figs 13 and 143). Records (Frič 1911) of Bourgueticrinus ellipticus and Antedon fischeri from the Korycany Member
(Peruc-Korycany Formation; Upper Cenomanian-lower Middle Turonian, at the localities Kamýk and Zbyslav) could not be verified as no original specimens have been found in the National Museum in Prague.

Bourgueticrinid columnals have also been recorded at Čížkovice near Lovosice (Frič 1889); this is now a disused quarry. In the 1970s, a new large quarry was opened near Úpohlavy, some $4 \mathrm{~km}$ southeast of the former quarry at Čížkovice. Recently, samples with relatively rich echinoderm faunas have been obtained from the new quarry. Current data on the geology and stratigraphy of the area and of some faunal groups are very good (Čech et al. 1996, Ekrt et al. 2001, Svobodová et al. 2002, Sklenář 2003, Vodrážka 2003, Laurin \& Uličný 2004, Wiese et al. 2004, Mikuláš 2006, Svobodová \& Žítt 2006, Vodrážka et al. in press). Samples with crinoids have also yielded numerous ophiuroid remains, which have recently been described in detail (Štorc \& Žítt 2008).

Crinoid material from Úpohlavy is represented mainly by dissociated ossicles but several cups (radials + basals) and proximalia of Bourgueticrinus and cups of Placometra have also been encountered. The comatulid Placometra is recorded for the first time from the $\mathrm{BCB}$. A restudy of the original specimens of Geinitz (1872), all from Saxonia (northeastern Germany) and deposited in the Staatliche 


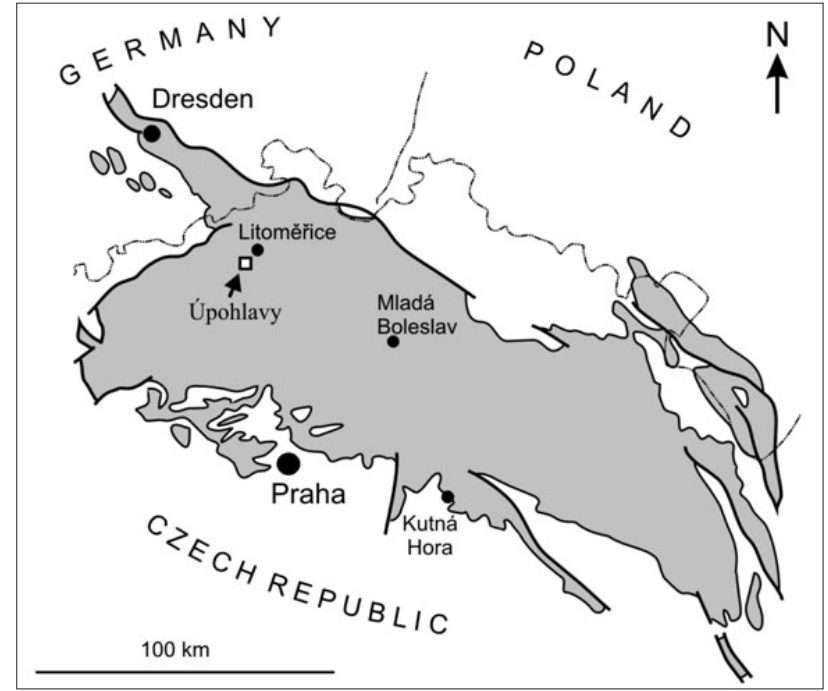

Figure 1. Sketch map of the Bohemian Cretaceous Basin (shaded), showing the location of Úpohlavy, source of the Late Turonian crinoid fauna.
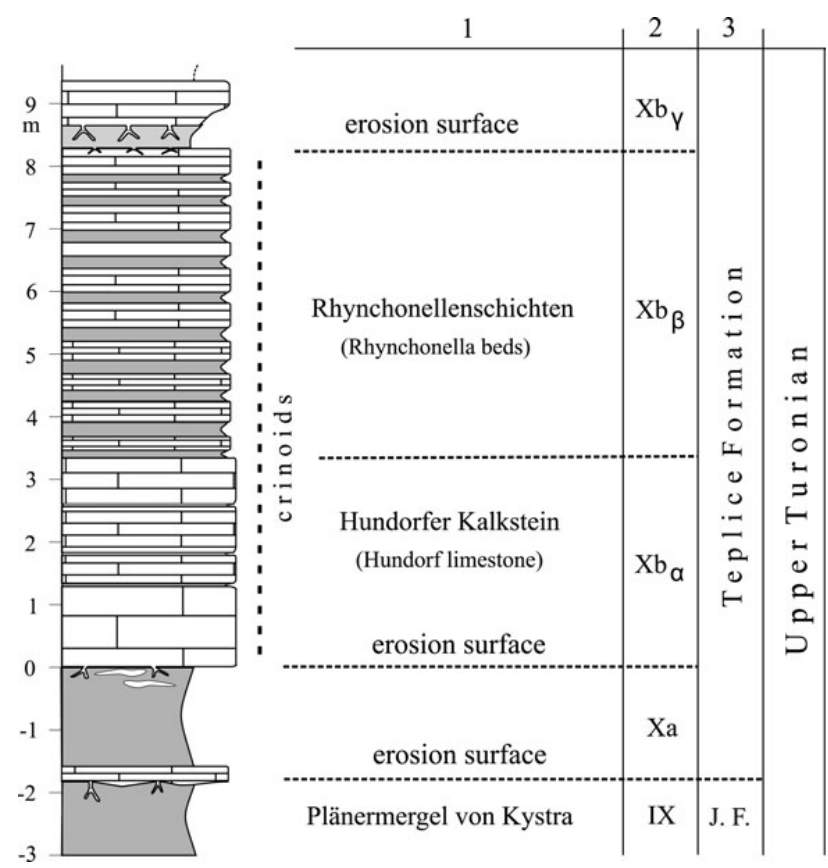

Figure 2. Lithology (shaded = marlstones; for other characters see text) and stratigraphy of the Upper Turonian strata, Úpohlavy section (lower part; modified after unpublished data by S. Čech, Czech Geological Survey, Prague) and distribution of crinoids studied; lithostratigraphic units as follows: 1 - Frič (1889), 2 - Váně in Krutský et al. (1975), 3 - Čech et al. (1980). Abbreviation: J.F. - Jizera Formation.

Naturhistorische Sammlungen at Dresden, has enabled closer comparison with the Bohemian material.

Problems surrounding the taxonomy of Bourgueticrinus were summarised by Klikushin (1982b), Jagt (1999) and Kjaer \& Thomsen (1999). Placometra was discussed by Jagt (1999). Rasmussen's (1961) monograph is of basic importance for the study of both genera.

\section{Geographical and geological setting}

The locality that yielded the crinoid material studied is a large working quarry (Čížkovické cementárny, a.s., Lafarge Cement) near the village of Úpohlavy, south of Lovosice and southwest of Litoměrice in northwest Bohemia (Fig. 1). Here, a succession of hemipelagic sediments of the Upper Turonian Teplice Formation [Xa, b, c(?)] is exposed, overlying the uppermost portion of the Jizera Formation (IX) (see Fig. 2). The boundary between the two units is close to the quarry floor. The overall thickness of the Teplice Formation is about 23-24 metres (Wiese et al. 2004) and the formation comprises an irregular alternation of hemipelagic limestones and marlstone beds. The crinoids come from an interval referred to as the Hundorf limestone $(\mathrm{Xb} \alpha)$, as well as from the overlying Rhynchonella beds $(\mathrm{Xb} \beta)$. The base of the Hundorf limestone is erosive, being characterised by a glauconite- and coprolite-rich bed (the so-called second coprolite horizon), which concentrates phosphatic intraclasts and phosphatised macrofauna. This horizon passes upwards into clayey limestone with only thin marl intercalations. The complete thickness of the Hundorf limestone is near 3 metres. The Rhynchonella beds consist of alternating marls and limestones and are about 5 metres thick. Both units contain rare accumulations of diminutive fossils (echinoderms, brachiopods, worms, bryozoans and others) and fragments and dissociated elements of these.

\section{Material and methods}

Crinoids were collected from the above-mentioned accumulations of organic debris. These accumulations most probably formed as burrow and small-scale erosional scour fill. The fills are mostly in the form of weathered-out, carbonate-rich, massive, mostly tabular or lense-shaped bodies several centimetres across and around $0.5-2 \mathrm{~cm}$ thick, often with a convex base, and a planar or slightly concave upper surface. In their uppermost parts, they are clay-rich and less compact than in basal portions, where fossil remains are densely packed and the rock is strongly cemented. These accumulations, when viewed in cross section at the quarry face, show a gradual lateral thinning from the thick central parts; the real extent of accumulations is not preserved if they are loose. In cross sections, they exceptionally reach $30 \mathrm{~cm}$ in size, demonstrating the maximum width of scoured seafloor depressions. About 25 scour fills were studied and most of these yielded at least isolated crinoid remains. In some of them, however, crinoids predominate. In the laboratory, the fills with crinoids were partially dissolved either in thick sulphuric acid or potassium hydroxide, and individual fossils were partly or completely released from the matrix. This method 
yielded numerous well-preserved crinoid ossicles. Some fills were only slightly chemically processed to maintain the original arrangement of accumulated ossicles within the rock.

\section{Systematic palaeontology}

Crinoid classification follows Jagt (1999). Brachials are described as separate items since it is uncertain to which species they belong. All material studied is deposited in the collections of the National Museum, Prague (registration numbers OS 544-554, O 6800-6804).

Class Crinoidea Miller, 1821

Subclass Cladida Moore \& Laudon, 1943

Infraclass Articulata Miller, 1821

Order Comatulidina A.H. Clark, 1908

Suborder Bourgueticrinina Sieverts-Doreck in Ubaghs, 1953

Family Bourgueticrinidae de Loriol, 1882

\section{Genus Bourgueticrinus d'Orbigny, 1841}

Type species. - Apiocrinites ellipticus Miller, 1821, by original designation.

\section{Bourgueticrinus ex gr. fischeri (Geinitz, 1872)} Figure 3A-D, F-N

?1844 Apiocrinites ellipticus Miller. - Reuss, p. 28 [Sauerbrunnberg, Kröndorf and other localities].

?1844 Apiocrinites ellipticus Miller. - Reuss, p. 43 [Luschitz].

?1845 Bourgueticrinus ellipticus d'Orbigny. - Reuss, p. 59, pl. 20, figs 28-33.

?1849 Bourguetocrinus ellipticus. - Geinitz, p. 230.

?1869 Bourguetocrinus ellipticus d'Orbigny. - Frič, p. 220.

$? 1869$ Bourguetocrinus ellipticus Goldfuss. - Frič, p. 221.

1872 Antedon Fischeri Geinitz, pp. 18, 19, pl. 6, figs 9a-d, 10a, b, 11, ?12.

1889 Mesocrinus Fischeri. - Frič, p. 37.

1895 Antedon Fischeri. - Frič, pp. 16, 105, 106, figs 13, 143.

1895 Antedon Fischeri Gein. - Jahn, pp. 143-145.

?1911 Bourgueticrinus ellipticus d'Orbigny. - Frič, p. 76.

?1911 Antedon Fischeri. - Frič, p. 76.

?1914 Antedon Fischeri. - Zahálka, p. 314 [Doubek near Oparno].

?2007 Bourgueticrinus ex gr. fischeri (Geinitz, 1872). - Jagt \& Salamon, p. 65, pl. 1, figs 1, 2.

For additional synonyms see Rasmussen (1961) and Jagt \& Salamon (2007).
Remarks. - The type specimen of Bourgueticrinus fischeri, illustrated by Geinitz (1872, pl. 6, fig. 9a, and assigned to Antedon), represents a complete individual, lacking arms. It is deposited in the Staatliche Naturhistorische Sammlungen von Sachsen at Dresden and bears registration number SAK 10586. The upper part of the specimen with a swollen columnal, some adjacent columnals and a cup (radials + basals), as well as radicular cirri in the distal stem, had broken off but these are kept in the same box as the main part of the specimen. A closer look at the cup clearly shows this to be the original of Geinitz's (1872) fig. 9b-d. The cup, now detached from the stem, must have been prepared free from the matrix (and later glued back in place) when the drawing was made. The latero-distal short branch [pointing to the right in Geinitz's (1872) fig. 9a] may represent part of a radicular cirrus, possibly belonging to the radix of this or some other individual. The specimen needs restoration and careful re-examination before anything more definite can be said about its nomenclaturial status. Rasmussen (1961, p. 166) noted that the whole specimen was actually reconstructed from ossicles of several individuals. It appears as if the rock type in which the specimen is preserved matches the greyish limestone at Strehlen, as indicated by Geinitz (1872).

Material. - Five cups (No. OS 544), seven proximalia (No. OS 545), one radial and one basal (No. OS 547), and 44 columnals (No. OS 554), all loose; two articulated basals and two radials in a piece of matrix (No. O 6801), one proximale in a piece of matrix (No. O 6800).

Description. - The cups (Fig. 3A, C, D; Table 1) are small, not exceeding heights of 2.1-2.4 $\mathrm{mm}(\mathrm{N}=5)$; the height of the radial ring equals $75 \%$, that of the basal ring $33.3 \%$ of total height of the largest cup (No. OS 544/1 in Table 1). The basal ring in the smallest cup (No. OS 544/5 in Table 1 ) is slightly taller ( $34.8 \%$ of cup height) than the radial ring. The ratio of radial and basal heights may even be 87\%: $30.4 \%$ of total height (No. OS 544/4). The cups are mostly slightly constricted in lateral view (Fig. 3D); in ventral view but only on the outer margin of the radial facets are they slightly pentalobate (Fig. 3A). The radial cavity is small with radial facets sloping outward (Fig. 3B) and interradially abutting in a sharp ridge (Fig. 3B) or a suture that may be depressed (Fig. 3A). The dorsal ligament fossa is large and the ligament pit variably deep (compare Fig. 3A and 3C). The interarticular ligament fossae are shallow and large, muscle fossae expressed but shallow, tapering in an interradial direction on rather tall interradial processes (Fig. 3C), tallest on the radial cavity margin. The axial canal is large, circular or slightly oval. The fulcral ridge is well developed (Fig. 3A). The basal cavity (Fig. 3D) is deep, mostly rounded-pentagonal to subpentagonal; the inner portion has more steeply-inclined walls. 
Table 1. Bourgueticrinus ex gr. fischeri. Measurements (in mm) of cups (without proximalia) using parameters of Kjaer \& Thomsen (1999, fig. 1), but we use "height" rather than their "length". A - height of radials, B - height of basals, C - height of cup without proximalia, D - upper diameter of cup, E - lower diameter of cup

\begin{tabular}{lccccc}
\hline specimen No. & A & B & C & D & E \\
\hline OS 544/1 & 1.8 & 0.8 & 2.4 & 3.4 & 2.3 \\
O3 544/2 & 1.8 & 0.7 & 2.1 & 2.8 & 1.9 \\
OS 544/3 & 1.6 & 0.7 & 2.1 & 2.8 & 1.9 \\
OS 544/4 & 2.0 & 0.7 & 2.3 & 2.6 & 2.3 \\
OS 544/5 & 1.7 & 0.8 & 2.3 & 2.6 & 1.8 \\
\hline
\end{tabular}

Table 2. Bourgueticrinus ex gr. fischeri. Measurements (in mm) of dissociated proximalia using parameters of Kjaer \& Thomsen (1999, fig. 1), but we use "height" rather than their "length"

\begin{tabular}{lccc}
\hline specimen No. & total height & proximal diameter & distal diameter \\
\hline OS 545/1 & 2.0 & 2.0 & 1.4 \\
OS 545/2 & 1.9 & 1.9 & 1.4 \\
OS 545/3 & 1.6 & 1.9 & 1.5 \\
OS 545/4 & 1.5 & 2.0 & 1.5 \\
OS 545/5 & 1.5 & 2.0 & 1.4 \\
OS 545/6 & 1.5 & 1.8 & 1.2 \\
OS 545/7 & 1.2 & 1.9 & 1.5 \\
\hline
\end{tabular}

Isolated proximalia are circular in cross section, conical, narrowing distally (Table 2), with slightly concave sides. Five articulation facets with basals are slightly concave, separated by low edges, encircling a deep pentagonal cavity as continuation of the inner part of the basal cavity. The distal articulation has a circular synostosis (Fig. 3J), and the axial canal is at least slightly pentagonal or pentalobate.

The columnals are cylindrical with slightly to strongly elliptical synarthries (Fig. 3F, H) of "bourgueticrinid" type (Jagt 1999). The articula of opposite columnal ends are oriented obliquely to perpendicularly. The synarthries are often very low and hardly distinguishable (Fig. $3 \mathrm{H}$ ). Some columnals have proximal or both articulations synostosial. These columnals, which are probably proximal ones, articulated possibly directly with the proximalia, and are mostly low, circular in cross section with proximal pentalobate axial canals (Fig. 3I, K).
Discussion. - These cups and columnals are identical with those from Strehlen, figured by Geinitz (1872, pl. 6, figs 9-11). The proximalia from Úpohlavy are relatively small and occur only isolated. However, none of them is as low as the one illustrated in Geinitz's (1872) specimen (assuming that that specimen has not been reconstructed; see Rasmussen 1961) - the most proximal subbasal element is not preserved in situ but has subsequently been released; it could not be identified by us in the Dresden collections). A comparison of data listed in Tables 1 and 2 shows that cups and proximalia from Úpohlavy can be combined on the basis of their respective diameters. The maximum complete height of the cup and proximale would then be around $4 \mathrm{~mm}$. A cup from the Santonian of Lipnik (Poland) decribed and figured by Jagt \& Salamon (2007, pp. 65-67, pl. 1, figs 1,2 ) and identified as $B$. ex gr. fischeri seems to be close, yet is not laterally constricted, and radials are slightly taller. We concur with those authors that this specimen resembles some juvenile indeterminate bourgueticrinid cups (see Jagt, 1999, pl. 30, figs 1-3) and, in addition, is close to B. hureae (Valette, 1917) and B.? suedicus (Carpenter, 1881) from the Campanian of southern Sweden and Belgium (see Jagt 1999, pl. 29, fig. 3; pl. 31, fig. 2).

Jagt \& Salamon (2007, p. 66) summarised the stratigraphic distribution of all species of Bourgueticrinus then known from the Turonian to Maastrichtian of Europe and of territories of the former Soviet Union, based on data supplied by Jäger (1987), Jagt et al. (1998), Jagt (1999), Jagt \& Odin (2001), Klikushin (1975, 1980, 1982a, b, 1983), Lee (1989), Merta (1972) and Rasmussen (1961). That table suggests that B. fischeri represents stratigraphically the oldest member of the genus. Both Rasmussen (1961) and Klikushin (1982b) recorded the species from the Santonian of England, western Ukraine, Turkmenistan and Kazakhstan, and Jäger (1979, 1980) extended the range into the Lower Campanian. A Late Turonian to Early Campanian range indeed represents a very long time interval, comparable amongst bourgueticrinids only with B. ellipticus (Miller, 1821) (Turonian-Santonian of western Europe). We agree with Jagt (1999) and Kjaer \& Thomsen (1999) that the current taxonomic scheme of bourgueticrinids suffers from poor documentation of the ontogeny, making it likely that the various ontogenetic stages could have been considered as separate species. New biometric analyses of larger sets of specimens may hopefully remove some of the inconsistencies in classification.

Figure 3. A-D, F-N - Bourgueticrinus ex gr. fischeri. $\bullet$ A - No. OS 544/3, dorsal cup in slightly oblique ventral view. $\bullet$ B - No. OS 545/1, proximale. - C - No. OS 544/2, dorsal cup in ventrolateral view. $\bullet$ D - No. OS 544/4, dorsal cup in dorsolateral view, with sutures between basals and radials inked in in right-hand photograph. $\bullet \mathrm{F}, \mathrm{H}, \mathrm{I}, \mathrm{K}-\mathrm{Nos}$. OS 546/1-4, columnals. $\bullet \mathrm{G}$ - proximale in matrix No. O 6800. $\bullet$ J - No. OS 545/3, proximale in oblique distal view. $\bullet$ L - No. OS 547/1, radial in inner view with faces for articulation of basals directed upwards. $\bullet$ M - No. OS 547/2, basal in "normal" orientation with articulation faces to radials directed upwards. $\bullet \mathrm{N}$ - part of matrix No. O 6801 with partially preserved cup; $\mathrm{b}-$ basals (with faces for radials oriented upwards), r - radials. • E - No. OS 546/5, indeterminate bourgueticrinid columnal of "rhizocrinid" type. Scale bars equal 500 $\mu$ m, except for Fig. 3E, where it represents $250 \mu \mathrm{m}$. 


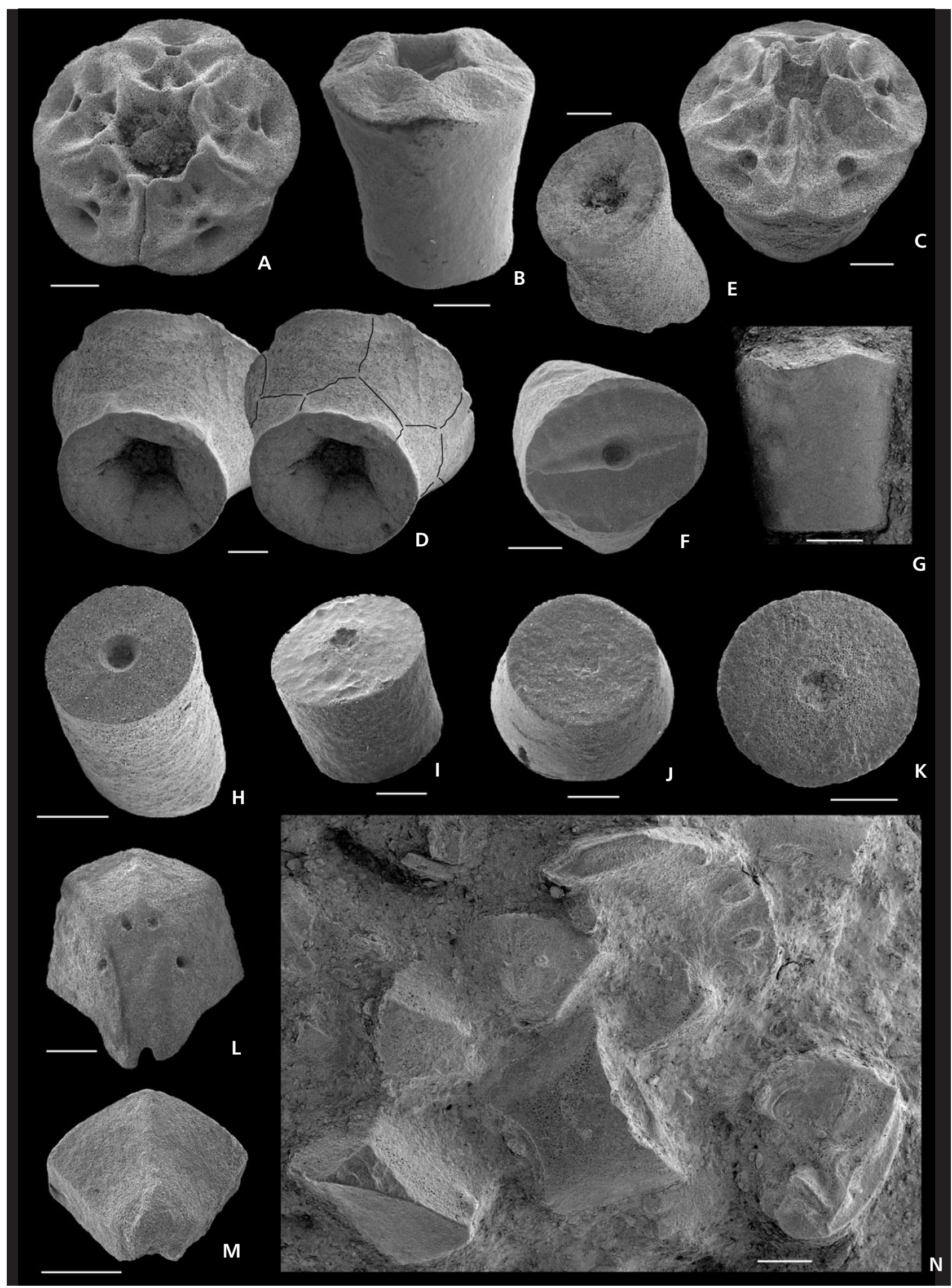


A "rhizocrinid" type of columnal (Fig. 3E) is rare in the assemblages studied; this must have belonged to another species, probably a bathycrinid (Jagt 1999).

\section{Bourgueticrinus ex gr. fischeri (Geinitz, 1872)?} Figures 4B-F, 5A-H

Material. - From a chemically-isolated concentration (scour fill) with numerous brachials, a single radial and ossicles of other echinoderms (No. O 6802); 14 isolated non-axillary brachials (No. OS 548); three isolated axillary brachials (No. OS 549).

Description. - The brachials are massive with mostly well-developed articula of various types; $\mathrm{IBr} 1$ is massive with a proximal muscular articulation corresponding to that of the radial; distally with synarthry (Fig. 4B-F). The ossicles are fairly tall, with muscle fossae forming two depressions corresponding to the muscle fossae of radials elevating near the radial cavity. Some IBr1 are symmetrical (Fig. 4B, D), some asymmetrical (Fig. 4C), often with lateral faces indicating contact with adjacent primibrachials. $\mathrm{IBr} 2$ is axillary, relatively low, with proximal synarthry (Fig. 5G-I). The highly asymmetrical muscular articulations of the axillaries correspond to some brachials, which could then be classed as IIBr1 (Fig. 4G, H), their distal articulations being synarthrial. No pinnular facets can be seen in any of the above-mentioned brachials. Obvious secundibrachials form syzygial pairs, in which the proximal member has a slightly concave (Figs 4J, 5B) and distal member (Fig. 5C) slightly convex articulum. The distal member of the pair can bear a pinnule socket (Fig. 5D; in Fig. 5C invisible but also present) so that the distal muscular articulation is oblique. Obliquity of muscular articulation of the proximal member of the syzygial pair is only slight if at all (see Figs 4I, 5A). Interpreted as secundibrachials also are elements with proximal synarthry and distal oblique muscular articulation plus a pinnular facet.

Notes. - The material comes from some chemically processed fills collected from the lower portion of the Rhynchonella beds and underlying Hundorf limestone. In addition to chemically uncovered surfaces (Fig. 4A), numerous dissociated brachials have been collected together with several bourgueticrinid columnals, proximalia and articulated cups (lacking proximalia). The great majority of these brachials is of a uniform type. Brr1 correspond to the radial facets of associated bourgueticrinid cups, and some other successive proximal arm ossicles could easily be identified in this assemblage. Most brachials probably belong to the more uniform distal secundibrachials. Although specific attribution of the majority of brachials available appears clear, only finds of articulated crowns will corroborate this. Some brachials may well have belonged to species with a "rhizocrinid" columnal type (Fig. 3E).
Infraorder Comatulidia A.H. Clark, 1908

Superfamily Tropiometroidea A.H. Clark, 1908

Family Pterocomidae Rasmussen, 1978

\section{Genus Placometra Gislén, 1924}

Type species. - Placometra mortenseni Gislén, 1924, by original designation.

Stratigraphy. - Turonian to Danian (Rasmussen 1961).

\section{Placometra ex gr. laticirra (Carpenter, 1880) Figure 6}

Synonymy. - See Jagt 1999, p. 91.

Material. - Two complete cups (No. OS 551); another cup embedded in matrix (rock fragment No. O 6804).

Description. - The two cups measured (Fig. 6; the third cup in matrix cannot be measured, but is slightly smaller) are pentagonal and small, with diameters (D) of 1.9 and $2 \mathrm{~mm}$ (the larger one is the specimen on the left in Fig. 6). The centrodorsals are low, with heights equalling 37 and $35 \% \mathrm{D}$, respectively. The height of the centrodorsal relative to that of the radial ring is $58 \%$ in both specimens; the centrodorsal is only slightly convex dorsally and smooth without cirral facets and any other structures. The lateral sides of the centrodorsal are rather steep with cirral facets directed nearly laterally; the cirral facets are large, with only slightly developed radiating crenellae along the margins. Facets are arranged in radial couples, within which one facet near the adradial margin is larger (ontogenetically older) and a second one slightly smaller or, rarely, still not fully developed; their morphology is not preserved in detail. The ventral structure of the centrodorsals is unknown, and not observable in the articulated cups. Basals are not seen externally. The radial ring is tall; radial facets steep and wide, distally with tall processes externally bearing large muscle fossae. The radials are only slightly overhanging the centrodorsal. The interarticular fossae are smaller, separated by a ridge from the muscle fossae. The dorsal ligament pit is large and wide. The axial canal is large and suboval in a direction perpendicular to the facet plane of symmetry. The fulcral ridge is wide and well expressed. The radial cavity is invisible.

Discussion. - Jagt (1999) synonymised P. laticirra (Carpenter, 1880) (type specimen from Turonian or Coniacian; Wiltshire, England) with two species described by Gislén (1924), i.e. P. scutata (Maastrichtian; Germany) and P. mortenseni (Upper Turonian; England). Only from the last-named species was a complete cup described. Jagt (1999) based his conclusions not only on previously 


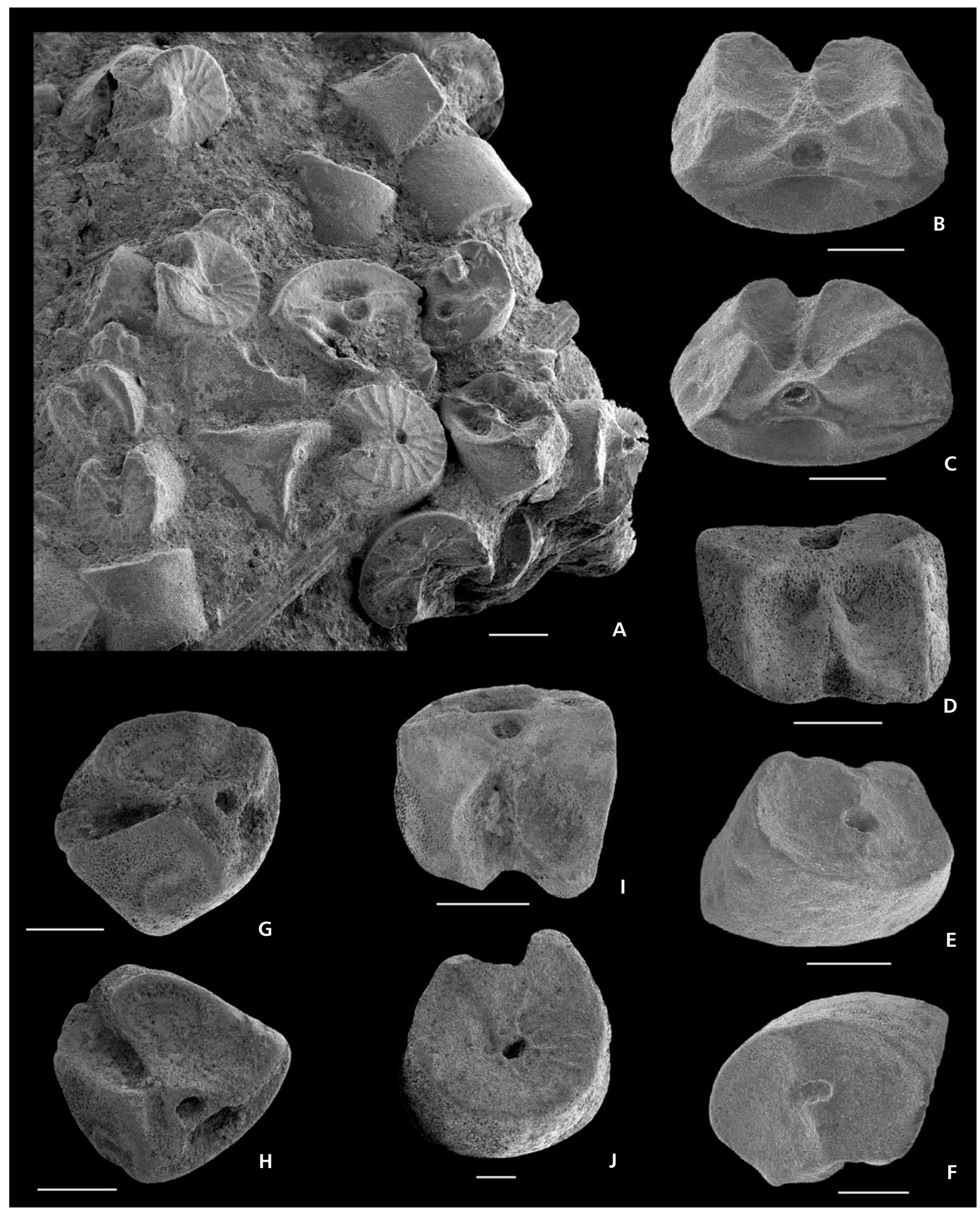

Figure 4. A-J - Bourgueticrinus ex gr. fischeri?. • A - part of a scour fill (No. O 6802) with prevailing brachials. • B-F - Nos OS 548/1-5, primibrachials 1; B, C - proximal view (articulation with radial facets), D - inner (ventral) view, E, F - distal views with synarthries. $\bullet$ G, H - No. OS $548 / 6$, probable secundibrachial in two positions, with synarthry on opposite side. $\bullet$ I, J - Nos. OS 548/7-8, probable secundibrachials with muscular articulation (I) and concave syzygial articulation on opposite side (J). Scale bars equal $500 \mu \mathrm{m}$, except for Fig. 4J, where it represents $200 \mu \mathrm{m}$. 
published records, but mainly on rich comparative material from the Upper Campanian and Upper Maastrichtian of the Netherlands and Belgium. In addition, some specimens from the Maastrichtian of Jasmund, Rügen were included. His study was based therefore not only on isolated centrodorsals but also on complete cups. However, in view of the fact that numerous specimens were separated both geographically and stratigraphically, species variation in individual "populations" could not be reliably evaluated (except for the new material described by Jagt 1999). Therefore, the material as a whole has not been interpreted at the level of species but rather referred to as a species group.

The present Czech material is too limited to contribute anything to the discussion of the variation of the species. The three cups are virtually identical to each other; in comparison with other published material (see above), they do show some morphological differences. The structure of cirral facets is similar to that in P. laticirra (see holotype in Carpenter, 1880, pl. 23, fig. 6 and Rasmussen 1961, pl. 52, fig. 3; see also the specimen in Jagt 1999, pl. 14, figs 11, 12), but crenellae are weakly developed or missing in the Czech specimens. Moreover, the radials in our specimens do not overhang the centrodorsal margins to the extent shown in other material, and the radial facets are not so steep as the ones illustrated in Jagt (1999, pl. 14, figs 4, 8; cup from the Upper Maastrichtian of Belgium). The Czech specimens seem to be, at least in their small overhang of radials over the centrodorsal, closer to $P$. mortenseni. The only known specimen of this species, from the Isle of Wight, is not an adequate basis for comparison. Placometra mortenseni was described from the Upper Turonian lata Zone. Two centrodorsals of $P$. laticirra from the same interval in Hampshire and Dorset are deposited in collections of Cambridge University, as noted by Rasmussen (1961). Additional material is needed for a better understanding of specific characters in the Czech "population" of Placometra.

\section{Placometra ex gr. laticirra (Carpenter, 1880)?}

\section{Figure $7 \mathrm{~A}-\mathrm{O}$}

Material. - Two arm segments and a few dissociated brachials arranged in a line or curve as they came loose from an arm segment, all found to co-occur with cups of Placometra ex gr. laticirra (see above) in the same scour fill (rock fragment No. O 6803). In addition, several isolated brachials in all orientations, plus another eight isolated brachials from other fills (No. OS 552).

Description. - The brachials found associated with cups are externally smooth and relatively tall, some with oblique muscular articulations proximally and distally (Fig. 7A,B) and with very well-expressed pinnular facets situated on the taller side. There are muscular articulations with extensive muscle fossae, shallow to only slightly-developed interarticular fossae, distinct aboral ligamentary fossa, and a large circular or suboval axial canal. Smaller brachials may have oblique, well-developed muscular articulation and opposite articulation in the form of cryptosyzygy (Fig. 7E). Some longer brachials are probably distal ones; these also bear pinnule facets. Those seen in Fig. 7C, F both have oblique muscular articulations. Together with these brachials very long cirrals were also found (Fig. 7G).

Notes. - All arm segments and associated brachials described above, found together with cups, are of the same morphological type. Their conspecificity with cups is suggested but some reservation is needed in this respect, because we did not identify any $\mathrm{Br} 1$, meaning that there is a gap with successive elements.

Some other dissociated brachials seen in clumps with bourgueticrinid and comatulid types in some other scour fills from which cups of Placometra cups were absent (matrix completely dissolved) appear identical to those described above, as far as external skeletal microstructure, type of articulation, pinnulation, etc. (Fig. 7H-O) are concerned. However, more precise assignment of these to a taxon presents more problems than for those found in association with arm segments and cups.

\section{Placometra? sp.}

Figure $8 \mathrm{~A}-\mathrm{H}$

Material. - Four loose brachials (No. OS 553); two brachials in a piece of matrix (No. O 6801).

Description. - The brachials have a dorsal and sometimes even lateral granular ornament with granules sometimes fusing into short ridges. Both the proximal and distal articulations are mostly oblique muscular; pinnular facets are well developed. In two brachials (Fig. 8A-C), there are

Figure 5. A-H - Bourgueticrinus ex gr. fischeri?. • A - No. OS 548/9, secundibrachial without pinnular facet, proximal view. • B - No. OS 548/10, secundibrachial of the same type as in Fig. A, distal view with concave syzygy. $\bullet$ C - No. OS 548/11, secundibrachial, proximal view with slightly convex syzygy and with pinnular facet (arrow) and slightly oblique muscular articulation on opposite side. $\bullet$ D - No. OS 548/12, secundibrachial in distal view with pinnular facet and convex syzygy on opposite side. • E - No. OS 548/13, secundibrachial of the same type, convex syzygy in proximal view. - F - No. OS 548/14, secundibrachial of the same type in ventral view. $\bullet$ G - No. OS 549/1, axillary primibrachial in distal view. $\bullet \mathrm{H}-\mathrm{No}$. OS 549/3, ditto, in ventral view. $\bullet$ I - No. OS 549/2, ditto, in oblique dorso-distal view. $\bullet$ J - No. OS 550, brachial of "Isocrinus" sp. embedded in matrix, distal view. Scale bars equal $500 \mu \mathrm{m}$ except, for Fig. 5C, F, where they represent $200 \mu \mathrm{m}$. 


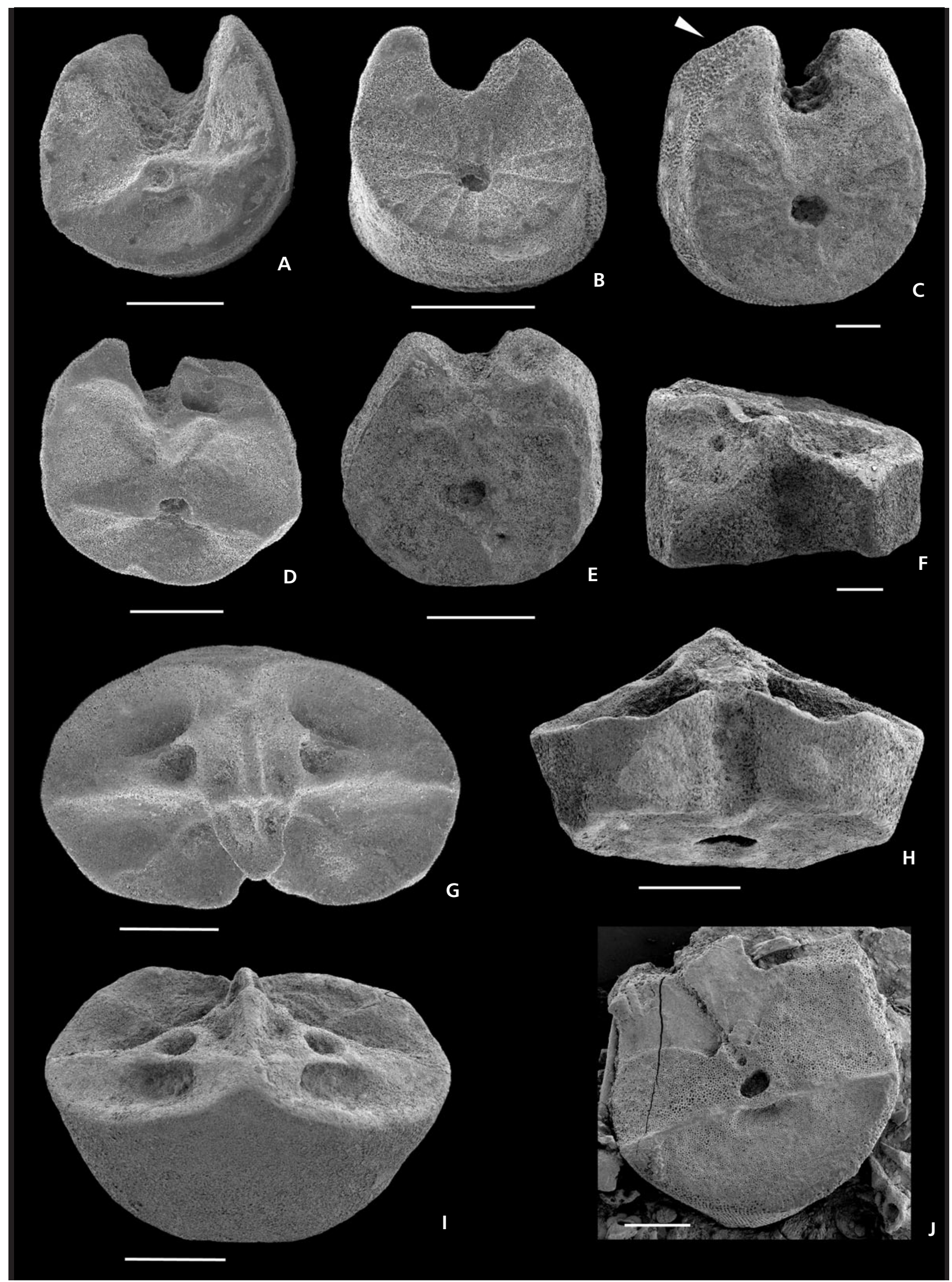




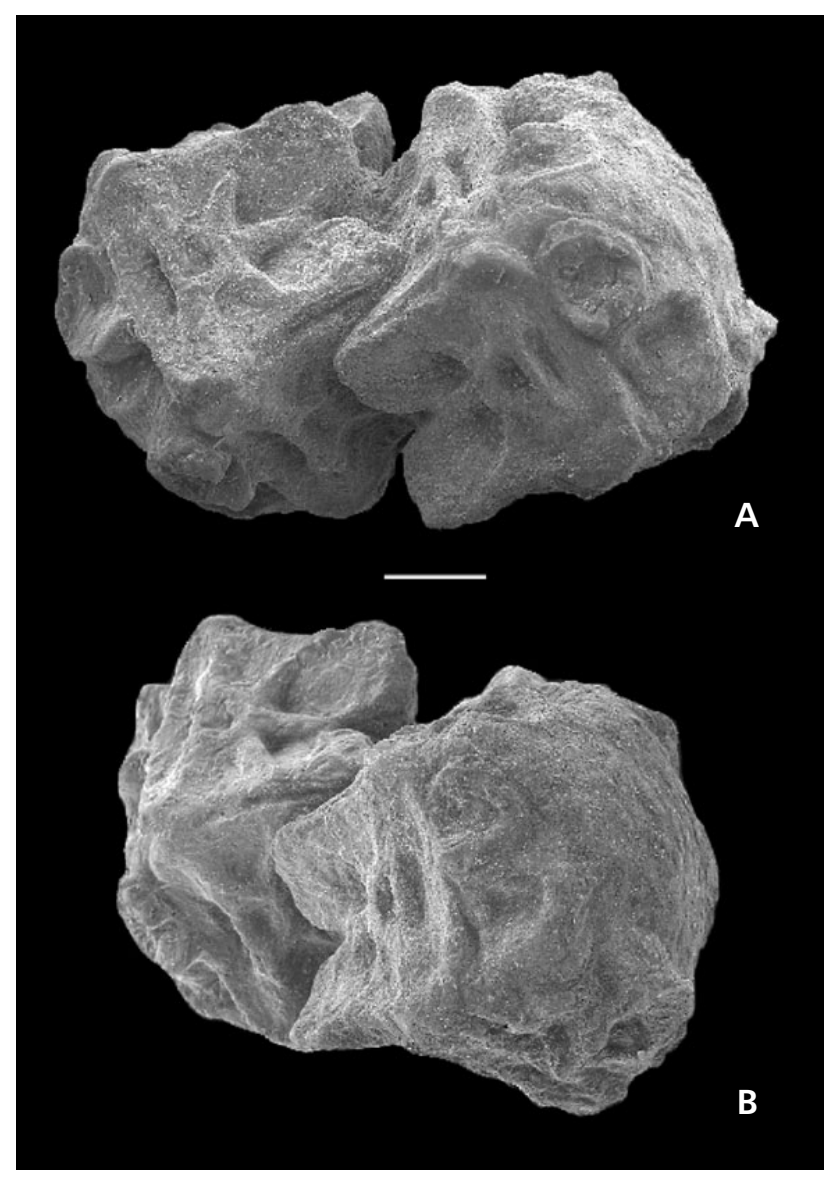

Figure 6. A, B - No. OS 551, Placometra ex gr. laticirra, two adjoined cups in different lateral views. Scale bar equals $500 \mu \mathrm{m}$.

distinct, yet thin adoral outgrowths centrally in close contact or even fused. These outgrowths are distally convex, and proximally they roof a cavity. Some elements without pinnules have one syzygial and one oblique muscular articulation (Fig. 8D).

Notes. - The outgrowths most probably functioned as extensive muscle attachment areas. A similar type of brachial was found in Early Turonian crinoid assemblages of BCB and considered to be notocrinid, as they co-occurred with centrodorsals and cups of Semiometra and Remesimetra (Žítt 1986). An indeterminate comatulid brachial from the
Zeven Wegen Member, Gulpen Formation (Upper Campanian, NE Belgium) figured by Jagt (1999, pl. 26, figs 8, 9) is also strongly enlarged ventrally in the area of the distal facet, but the outgrowth is concave distally.

Order Isocrinida Sieverts-Doreck in Moore, 1952

Suborder Isocrinina Sieverts-Doreck in Moore, 1952

Fam. gen. et sp. indet.

\section{"Isocrinus" sp.}

Figure 5J

Material. - One brachial embedded in matrix (No. OS 550).

Description. - The single brachial found, probably secundibrachial, shows a well-developed, relatively flat oblique muscular articulation with a pinnule facet, and is wide and seems to be low (being still embedded in matrix).

Note. - The species to which this brachial belongs had to be extremely rare at Úpohlavy, similar to the isocrinid occurrence in the Middle and Upper Turonian of the BCB as a whole. Only one subpentagonal columnal is present in a scour-fill concentration and this was unfortunately destroyed despite laborious chemical preparation. It was, however, similar to a specimen from Strehlen, described and figured by Geinitz (1872, pp. 17, 18, pl. 6, figs 1, 2) as Pentacrinus lanceolatus Römer.

\section{Notes on taphonomy and life habits}

The disarticulation of the crinoid skeletons in the scour fills was nearly complete, and only occasionally were some articulated ossicles found (see above). Individual ossicles in the assemblages are mostly undamaged and well preserved with regard to morphology and skeletal structure, their fragmentation and abrasion being mostly insignificant. Post-mortem disarticulated crinoid ossicles and some still-articulated skeletal segments were probably transported over varying distances and/or for varying time intervals. In each case, abrasion and dissolution were reduced apparently thanks to the soft muddy nature of the seafloor

Figure 7. A-F-Brachials identified as Placometra ex gr. laticirra? on the surface of scour fill (No. O 6803) in which also the cups (Fig. 6) were found. - $\mathrm{G}$ - cirral in the same fill. $\bullet \mathrm{H}-\mathrm{O}$ - isolated secundibrachials(?) of the same species with distal and proximal articulations being oblique muscular. $\bullet \mathrm{H}-$ No. OS 552/1, ventral view, distally upwards. $\bullet$ I - No. OS 552/2, proximal view (position of pinnule on opposite side marked by arrow). $\mathrm{J}-\mathrm{No}$. OS $552 / 3$, lateral view, distally upwards, pinnule $=$ white arrows, positions of fulcral ridges $=$ thin, black lines. $\bullet \mathrm{K}-\mathrm{No}$. OS $552 / 4$, more distal secundibrachial(?) in lateral view, distally upwards(?), no pinnule, positions of fulcral ridges $=$ thin, black lines. $\bullet$ L - No. OS 552/5, long brachial in distal view, pinnule $=$ white arrow. $\bullet \mathrm{M}-$ No. OS 552/6, similar long brachial in proximal view. $\bullet \mathrm{N}-$ No. OS 552/7, similar brachial in lateral view, distally upwards. $\bullet$ O No. OS 552/8, a brachial very similar to that in Fig. 7H, distal view. Scale bars equal $200 \mu$ m, except for Fig. 7A-E, G, where they represent $500 \mu \mathrm{m}$. 

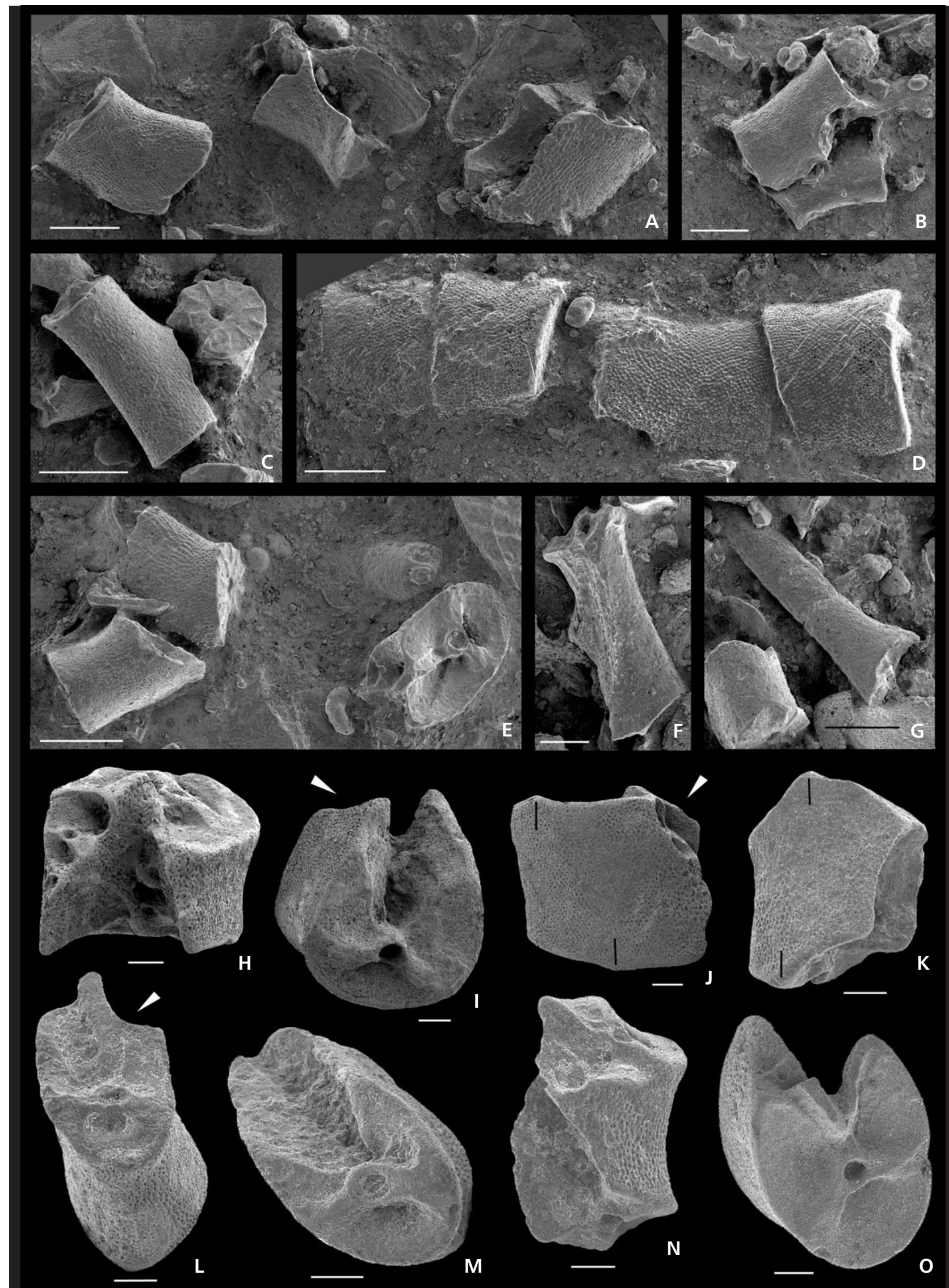
and probably due to a comparatively low amount of simultaneously transported coarse particles.

Polyspecific ossicle associations could have resulted from scour mixing over large areas of the seafloor. Coincident winnowing could have enriched the associations with remains of older populations; however, small elements (cirrals, pinnulars) most probably have been lost. The existence of large source areas of crinoid debris is supported by the relatively rare occurrence of scour fills, which indicates that depressed scours capable of trapping mobile skeletal debris were relatively uncommon on the seafloor. If, however, articulated skeletal debris occurs, short-distance transport and death of crinoids, in bourgueticrinids even corresponding to the site of attachment in life, near these scoured depressions is indicated.

In view of the assumed mode of formation of scour fills, recognition of crinoid distribution on the seafloor is impossible. Regarding stratigraphic distribution, only bourgueticrinids are abundant enough to allow a tentative estimate that they were commoner in the lower part of the section (units $\mathrm{Xb}_{\alpha}$ and lower part of $\mathrm{Xb}_{\beta}$ ). Comatulids may tentatively be regarded as rather rare components of benthic communities at all levels sampled. The rare, yet ubiquitous, presence of comatulids may be explained by their skeletal construction. After death, their multi-armed crowns could easily supply wide bottom areas with ossicles.

Very few data are available on the life habits of the crinoids studied. The two stalked species found at Úpohlavy could have attached either directly to the substrate, or, less probably, to hard bottom objects. The stem of Bourgueticrinus ex gr. fischeri was probably short, bearing radicular cirri (as based on specimens illustrated by Geinitz 1872 and Frič 1895) used for anchorage. We prefer to see this as fixation to some skeletal debris (possibly in gradually developing scour fills) rather than as attachment directly to the soft calcareous, ooze-like marly sediment. Another type of fixation was described by Jagt (1999) for a bourgueticrinid with "rhizocrinid" columnals; a radix-like plate of this form was found attached to a belemnite guard (Jagt 1999, pl. 33, fig.10). Yet another instance was noted by Rasmussen (1961, pl. 24, fig.1), who identified this as Bourgueticrinus sp.; it has the form of a small plate attached to an echinoid test. Unfortunately, there is no indication of any attachment structure of Bourgueticrinus at Úpohlavy.

The "Isocrinus" sp. was fixed by cirri to the soft substrate either permanently or temporarily when drifting (see e.g., Rasmussen 1977, Roux 1987). The paucity of isocrinid remains demonstrates that this group was rare in these communities; the near-complete absence of isocrinid cirrals and pinnulars, which were probably very numerous, can be explained by episodes of strong winnowing.

The stalkless crinoid Placometra ex gr. laticirra pos- sessed only few (about ten unequally developed) cirri, which were probably rather thick. By comparison, some recent comatulids live perched high on prominent bottom objects (Meyer 1973, Meyer \& Macurda 1977), attached by numerous long cirri. Other comatulids rather depend on the infrastructure of the substrate, e.g., Tropiometra carinata carinata (Lamarck) (see Meyer 1973), a species which has, similar to Placometra, a flat, low centrodorsal with lateral cirri and which is often attached within crevices, sometimes even elevated or on a flat bottom. Placometra ex gr. laticirra could well have been attached between sponge branches or to their bases, below dead sponges or bivalve shells, etc.; both substrates are locally well represented within the Rhynchonella beds at Úpohlavy. For a summary and discussion of taphonomy and palaeoecology of Late Cretaceous crinoids, see Jagt (2000).

\section{Conclusions}

Until now, Late Turonian crinoids from the BCB were unknown. At Úpohlavy, they have now been discovered but only in local accumulations in scour fills, which are rich also in other invertebrate faunal groups (ophiuroids, asteroids, small brachiopods, worms, bryozoans, etc.). The predominance in the crinoid assemblages of brachials over other ossicles, mainly cups, is typical of many scour fills. Selective transport probably played a role in this concentration (especially by removing minute elements such as cirrals and pinnulars). This predominance of brachials is of importance for the record of crinoid taxa. Considering a similar preservation potential of the respective species, their taxonomic signature must be most complete here. This has been confirmed at Úpohlavy. However, the morphological uniformity and easy post-mortem dispersal over large bottom areas, leading to the ubiquity of brachials, increase the risk of misidentifying taxa when trying to associate brachials with other skeletal parts. For this reason, brachials are described separately. The same, although to a lesser extent because some stemless species were present in these communities, applies to columnals.

At least five crinoid species seem to have contributed to the benthic communities in the Úpohlavy area. The commonest is the small-sized Bourgueticrinus ex gr. fischeri, which had ten pinnulated arms probably composed of fairly massive brachials joined by synarthries, syzygies and strongly-developed oblique muscular articulations. Isolated brachials are described separately as Bourgueticrinus ex gr. fischeri?. Bourgueticrinus ex gr. fischeri from the lower part of the Teplice Formation in Bohemia (and from Strehlen, Saxonia) seems to be stratigraphically the oldest-known described species. Stratigraphically yet older occurrences of Bohemian bourgueticrinids (Upper 


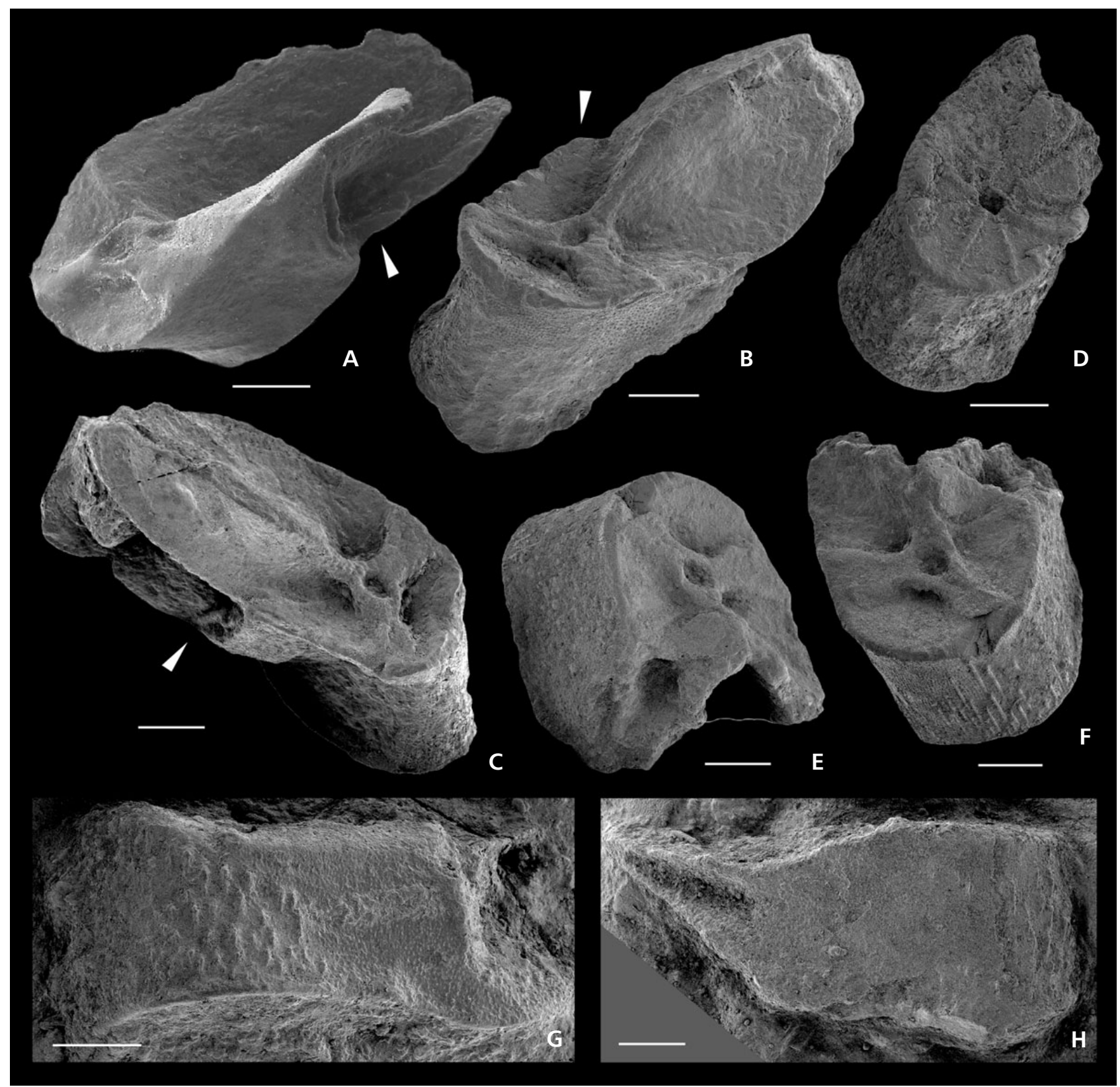

Figure 8. Brachials of Placometra? sp. with rough tubercles in lines on dorsal sides. $\bullet$ A-C - brachials with adoral spoon-like outgrowths. $\bullet$ A - No. OS $553 / 1$, proximal view, pinnule $=$ white arrow (indentation on right-hand side above pinnular facet is a fracture). $\bullet$ B, C - No. OS 553/2, a brachial in two lateral-distal views, position of pinnule $=$ white arrows. $\bullet$ D - No. OS 553/3, pinnule-less brachial with a syzygy and oblique muscular articulation on the opposite side. $\bullet$ E, F - No. OS 553/4, a brachial in two oblique distal views. $\bullet \mathrm{G}, \mathrm{H}-$ two brachials in lateral views in matrix No. O 6801 . Scale bars equal $500 \mu \mathrm{m}$.

Cenomanian-lower Middle Turonian) mentioned by Frič (1911) are not verified but are probable [see recent finds of bourgueticrinid columnals in the Cenomanian of Poland (Salamon 2007)]. Another bourgueticrinid (probably bathycrinid) species with "rhizocrinid" columnals was extremely rare in the Úpohlavy community. Stalkless comatulids probably are represented by two species, with Placometra ex gr. laticirra with a flat centrodorsal and a low number of strong cirri recognised on the basis of com- plete cups. Poorly-known comatulid arm ossicles are described as Placometra ex gr. laticirra? (some arm segments preserved) and Placometra? sp. with conspicuously ornamented brachials. The rare isocrinid occurrence is exemplified by a single brachial. The taphonomical data suggests various possible life habits and palaeoecology as described.

The basal parts of the Teplice Formation are correlatable with the Strehlen limestone in Saxony (e.g., Tröger 2001, fig. 4). Not only are the lithologies virtually identical 
but also the faunal contents. Many specimens described from Strehlen by Geinitz (1872) are deposited in the Staatliche Naturhistorische Sammlungen at Dresden. For crinoid studies, most important is the type specimen of Bourgueticrinus fischeri, which might represent a nearcomplete individual of this species; however, the status of this specimen is still unclear and a detailed re-examination is needed to confirm or reject Rasmussen's (1961, p.166) view that it was reconstructed from ossicles of different individuals. The Dresden collections also contain samples of the Strehlen limestone with accumulations of small macrofauna closely resembling burrow or scour fills from Úpohlavy. Similar or identical crinoid ossicles (mainly bourgueticrinid columnals and brachials) are identifiable within some of them. A closer comparison of the BCB and Saxonian associations in the future could yield further interesting data.

\section{Acknowledgements}

We thank J.W.M. Jagt (Natuurhistorisch Museum Maastricht, Maastricht, The Netherlands) for commenting on an earlier typescript; J. Sklenář (National Museum, Prague) for museum work; S. Švarcová (Institute of Inorganic Chemistry ASCR, Řež near Prague) for SEM micrographs; and the management of the Čížkovická cementárna, a.s. (Lafarge Cement) for making our work at Úpohlavy quarry possible. This research was undertaken within project Z 30130516 of the Institute of Geology ASCR, Prague and grant project No. 205/06/0842 of the Grant Agency of the Czech Republic.

\section{References}

CARPenter, P.H. 1880. On some new Cretaceous Comatulae. Quarterly Journal of the Geological Society of London 36, $549-558$.

CARPENTER, P.H. 1881. On two new crinoids from the Upper Chalk of southern Sweden. Quarterly Journal of the Geological Society of London 37, 128-136.

ClARK, A.H. 1908. Description of new species of crinoids, chiefly from the collections made by U.S. Fisheries steamer "Albatross" at the Hawaiian Islands in 1902; with remarks on the classification of the Comatulida. United States National Museum Proceedings 34(1908), 209-239.

ČECH, S., KLEIN, V., KŘíž, J. \& VALEČKA, J. 1980. Revision of the Upper Cretaceous stratigraphy of the Bohemian Cretaceous Basin. Věstník Ústředního ústavu geologického 55, 277-296.

ČECH, S., HRADECKÁ, L., LAURIN, J., ŠTAFFEN, Z., ŠVÁBENICKÁ, L. \& ULIČNÝ, D. 1996. Úpohlavy quarry. Record of late Turonian sea-level oscillations and synsedimentary tectonic activity Stratigraphy and Facies of the Bohemian-Saxonian Cretaceous Basin. Field Trip Guide, $5^{\text {th }}$ International Cretaceous Symposium, Freiberg, 32-42.
EKRT, B., KoŠŤÁK, M., MAZUCH, M., VALÍČEK, J., VOIGT, S. \& WIESE, F. 2001. Short note on new records of late Turonian (Upper Cretaceous) marine reptile remains from the Úpohlavy quarry (NW Bohemia, Czech Republic). Bulletin of the Czech Geological Survey 76, 101-106.

FRIČ, A. 1869. Studien im Gebiete der böhmischen Kreide-Formation. II. Paläontologische Untersuchungen der einzelnen Schichten in der böhmischen Kreideformation. Archiv der naturwissenschaftlichen Landesdurchforschung von Böhmen $1,183-242$.

FRIČ, A. 1889. Studie v oboru křídového útvaru v Čechách. Paleontologické prozkoumání jednotlivých vrstev. IV. Teplické vrstvy. Archiv pro př́rodovědné prozkoumání Čech 7 , $1-114$.

FRIČ, A. 1895. Studie v oboru křídového útvaru v Čechách. Paleontologické prozkoumání jednotlivých vrstev. V. Březenské vrstvy. Archiv pro přirodovědné prozkoumáni Čech 9, $1-128$.

FRIČ, A. 1911. Studie v oboru českého útvaru křídového. Paleontologický výzkum jednotlivých vrstev. Doplněk k 1. dílu Archivu I, Sekce II. Illustrovaný seznam zkamenělin cenomanních vrstev korycanských. Archiv pro př́rodovědecký výzkum Čech 15, 1-101.

GEINITZ, H.B. 1849-1850. Das Quadersandsteingebirge, oder Kreidegebirge in Deutschland. 1849, 1-96; 1850, 97-293. Craz \& Gerlach, Freiberg.

GEINITZ, H.B. 1872-1875. Das Elbthalgebirge in Sachsen. 2. Der mittlere und obere Quader. I. Palaeontographica 20, $1-245$.

GISLÉN, T. 1924. Echinoderm Studies. Zoologiska Bidrag från Uppsala 9, iv + 1-316.

JÄGER, M. 1979. Drei- und vierstrahlige Funde der Crinoidengattung Bourgueticrinus Orbigny, 1841 aus dem Untercampan (Oberkreide) von Höver bei Hannover. Berichte der naturhistorischen Gesellschaft zu Hannover 122, 79-89.

JÄGER, M. 1980. Ungewöhnliche Crinoiden aus dem UnterCampan (Oberkreide) von Höver bei Hannover. Berichte der naturhistorischen Gesellschaft zu Hannover 123, 63-77.

JÄGER, M. 1987. Zweite Mitteilung über seltene Crinoiden aus der Oberkreide der Umgebung von Hannover. Berichte der naturhistorischen Gesellschaft zu Hannover 129, 113-124.

JAGT, J.W.M. 1999. Late Cretaceous-Early Palaeogene echinoderms and the K/T boundary in the southeast Netherlands and northeast Belgium - Part 2: Crinoids. Scripta Geologica 116, 59-255.

JAGT, J.W.M. 2000. Late Cretaceous-Early Palaeogene echinoderms and the K/T boundary in the southeast Netherlands and northeast Belgium - Part 6: Conclusions. Scripta Geologica 121, 505-577.

JAGT, J.W.M., DONOVAN, S.K., DECKERS, M.J.M, DORTANGS, R.W., KUYPERS, M.M.M. \& VELTKAMP, C.J. 1998. The Late Maastrichtian bourgueticrinid crinoid Dunnicrinus aequalis (d'Orbigny, 1841) from The Netherlands and Belgium. Bulletin de l'Institut royal des Sciences naturelles de Belgique, Sciences de la Terre 68, 129-154.

JAGT, J.W.M. \& ODIN, G.S. 2001. Campanian-Maastrichtian cri- 
noids (Echinodermata) from Tercis les Bains (Landes), 635-644. In ODIN, G.S. (ed.) The Campanian-Maastrichtian Stage Boundary. Characterisation at Tercis les Bains (France) and Correlation with Europe and other Continents. Developments in Palaeontology and Stratigraphy 19. Elsevier, Amsterdam.

JAGT, J.W.M. \& SALAMON, M.A. 2007. Late Cretaceous bourgueticrinid crinoids from southern Poland - preliminary observations. Scripta Geologica 134, 61-76.

JAHN, J.J. 1895. Einige Beiträge zur Kenntniss der böhmischen Kreideformation. Jahrbuch der kaiserlich-königlichen geologischen Reichsanstalt Wien 45, 125-218.

KJAER, C.R. \& THOMSEN, E. 1999. Heterochrony in bourgueticrinid sea-lilies at the Cretaceous/Tertiary boundary. Paleobiology 25, 29-40.

KLIKUSHIN, V.G. 1975. Novye burguetikrinidy (Crinoidea) Mangyshlaka. Paleontologicheskiy Sbornik 12, 119-121. [in Russian]

KLIKUSHIN, V.G. 1980. Morskie lilii iz verkhnemelovych otlozhenii SSSR. Byulleten' Moskovskogo Obshchestva Ispytatelej Prirody, Otdel geologii 55, 80-84. [in Russian]

KLIKUSHIN, V.G. 1982a. O pozdnemelovykh morskikh liliiakh Mangyshlaka. Paleontologicheskiy Zhurnal 4, 98-103 [in Russian]

KLIKushin, V.G. 1982b. Cretaceous and Paleogene Bourgueticrinina (Echinodermata, Crinoidea) of the USSR. Geobios 15, 811-843. DOI 10.1016/S0016-6995(82)80034-X

KLIKUSHIN, V.G. 1983. Distribution of crinoidal remains in the Upper Cretaceous of the U.S.S.R. Cretaceous Research 4, 101-106. DOI 10.1016/0195-6671(83)90027-7

Krutský, N., VÁNĚ, M., HolÁ, A. \& HercogovÁ, J. 1975. Turon a Coniak v dolním Poohří. Sborník geologických věd, Řada G 27, 99-142.

LAURIN, J. \& ULIČNÝ, D. 2004. Controls on a shallow-water hemipelagic carbonate system adjacent to a siliciclastic margin: example from Late Turonian of central Europe. Journal of Sedimentary Research 74, 697-717.

DOI 10.1306/020904740697

LEE, C.P. 1989. A new species of Bourgueticrinus from the Coniacian Chalk of Rochester, Kent, England. Mesozoic Research 2, 91-96.

LORIOL, P. DE. 1882. Description of a new species of Bourgueticrinus. Journal of the Cincinnati Society of Natural History $5,118$.

MERTA, T. 1972. Bourgueticrinus utriculatus (Valette) from the Senonian of the Cracow Upland. Acta Geologica Polonica 22, 541-544.

MEYER, D.L. 1973. Feeding behavior and ecology of shallowwater unstalked crinoids (Echinodermata) in the Caribbean Sea. Marine Biology 22, 105-129. DOI $10.1007 / \mathrm{BF} 00391776$

MEYER, D.L. \& MACURDA, D.B. JR. 1977. Adaptive radiation of the comatulid crinoids. Paleobiology 3, 74-82.

MIKULÁŠ, R. 2006. Ichnofabric and substrate consistency in Upper Turonian carbonates of the Bohemian Cretaceous Basin (Czech Republic). Geologica Carpathica 57, 79-90.
MILlER, J.S. 1821. A natural history of the Crinoidea or lilyshaped animals, with observation on the genera Asterias, Euryale, Comatula, and Marsupites. 150 pp. Bryan \& Co., Bristol.

MoORE, R.C. 1952. Crinoids, 604-652. In MOORE, R.C., LALICKER, G. \& FISCHER, A.G. (eds) Invertebrate fossils. McGraw-Hill, New York, Toronto, London.

MoORE, R.C. \& LAUDON, L.R. 1943. Evolution and Classification of Paleozoic Crinoids. Geological Society of America, Special Paper 46, 1-153.

ORBIGNY, A.D. D' 1840-1858. Histoire naturelle générale et particulière des Crinoides, vivans et fossiles, comprenant la description zoologique et géologique de ces animaux. 1840, pp. 1-64, pls 1-12; 1841, pp. 65-96, pls 13-18; 1858, pp. 97-98. Paris.

RASMUSSEN, H.W. 1961. A monograph on the Cretaceous Crinoidea. Biologiske Skrifter udgivet af det Kongelige Danske Videnskabernes Selskab 12, 1-428.

RASMUSSEN, H.W. 1977. Function and attachment of the stem in Isocrinidae and Pentacrinitidae: review and interpretation. Lethaia 10, 51-57. DOI 10.1111/j.1502-3931.1977.tb00591.x

RASMUSSEN, H.W. 1978. Articulata, T813-T927. In MOORE, R.C. \& TEICHERT, C. (eds) Treatise on Invertebrate Paleontology, Part T, Echinodermata 2. Geological Society of America \& The University of Kansas Press, Boulder \& Lawrence.

REUSS, A.E. 1844. Geognostische Skizzen aus Böhmen. 2. Die Kreidegebilde des westlichen Böhmens, ein monographischer Versuch. 304 pp. C.W. Medau \& Comp., Praha.

REUSS, A.E. 1845-1846. Die Versteinerungen der böhmischen Kreideformation. 1845, 58 pp.; 1846, 148 pp. E. Schweizerbart, Stuttgart.

RouX, M. 1987. Evolutionary ecology and biogeography of recent stalked crinoids as a model for the fossil record, 1-53. In JANGOUX, M. \& LAWRENCE, J.M. (eds) Echinoderm studies 2. A.A. Balkema, Rotterdam/Brookfield.

SALAMON, M.A. 2007. First record of bourgueticrinid crinoids from the Cenomanian of southern Poland. Cretaceous Research 28(3), 495-499. DO] 10.1016/j.cretres.2006.07.005

SKLENÁR̆, J. 2003. Brachiopoda lokality cementárna Úpohlavy u Lovosic (svrchní turon). Sborník vědeckých prací Vysoké školy báňské (Ostrava) 49, 69-70.

SVOBODOVÁ, M., LAURIN, J. \& ULIČNÝ, D. 2002. Palynomorph assemblages in a hemipelagic succession as indicators of transgressive-regressive cycles: example from the Upper Turonian of the Bohemian Cretaceous Basin, Czech Republic, 249-267. In WAGREICH, M. (ed.) Aspects of Cretaceous Stratigraphy and Paleobiogeography. Schriftenreihe der Erdwissenschaftlichen Kommission 15.

SvoBodovÁ, M. \& ŽíTT, J. 2006. Palynomorph distribution and new palaeoenvironmental data (Upper Turonian, Bohemian Cretaceous Basin). $7^{\text {th }}$ European Palaeobotany-Palynology Conference, 6.-12.9.2006, National Museum, Praha. Book of Conference Abstracts, 136.

ŠTORC, R. \& ŽíTT, J. 2008. Late Turonian ophiuroids (Echinodermata) from the Bohemian Cretaceous Basin, Czech Republic. Bulletin of Geosciences 83(2), 123-140. 
TRÖGER, K.A. 2001. Hans Bruno Geinitz und seine Bedeutung für die heutige Oberkreide-Forschung. Geologica Saxonica 46/47, 83-91.

Ubaghs, G. 1953. Classe des Crinoïdes, 658-773. In PIVETEAU, J. (ed.) Traité de Paléontologie, III, Onychophores, Arthropodes, Échinodermes, Stomocordés. Masson et Cie, Paris.

VALETTE, A. 1917. Note sur les crinoïdes de la craie blanche. Bulletin de la Société des Sciences et d'Histoire naturelle de l'Yonne 70(1916), 79-178.

VODRÁŽKA, R. 2003. Porifera české křídové pánve - půda úrodná, pole neorané. Sborník vědeckých prací Vysoké školy báňské (Ostrava) 49, 58-60.

VODRÁŽKA, R., ČECH, S., SKLENÁR̆, J., HRADECKÁ, L. \& LAURIN, J. in press. Phosphatic lags from condensation intervals important source of palaeoecological and biostratigraphic data (Býčkovice, Bohemian Cretaceous Basin). Cretaceous Research.

Wiese, F., ČECH, S., EKRT, B., KOŠŤÁK, M. \& VOIGT, S. 2004. The Upper Turonian of the Bohemian Cretaceous Basin (Czech Republic): integrated stratigraphy and palaeoceano- graphy of a gateway to the Tethys. Cretaceous Research 25, 329-352. DOI 10.1016/j.cretres.2004.01.003

ZAHÁLKA, Č. 1914. Útvar křídový v Českém středohoři. 465 pp. Published by author, Roudnice.

ŽíTT, J. 1986. Lilijice vybraných lokalit př́bojového vývoje české svrchni křidy kolinské oblasti (Crinoids of the selected nearshore localities of the Bohemian Upper Cretaceous, Kolin lithofacial region). 94 pp. Final report, Institute of Geology and Geotechnics ČSAV, Prague.

ŽíTT, J. 1993. New data on crinoids from the coastal deposits of the Bohemian Cretaceous (Kolín lithofacies area). Zprávy o geologických výzkumech v roce 1992, 87-88. [in Czech]

ŽíTT, J. 1996. Cyathidium Steenstrup (Crinoidea) in the Upper Cretaceous of Bohemia (Czech Republic). Journal of the Czech Geological Society 41, 233-239.

ŽítT, J., VODRÁŽKA, R., HRADECKÁ, L., SVOBODOVÁ, M. \& ZÁGORŠEK, K. 2006. Late Cretaceous environments and communities as recorded at Chrtníky (Bohemian Cretaceous Basin, Czech Republic). Bulletin of Geosciences 81(1), 43-79. DOI 10.3140/bull.geosci.2006.01.043 